\title{
VETERINARY SURGERY AND GYNECOLOGY IN THE ANCIENT EGYPT
}

\author{
BAHAAELDEEN A. ABEDELLAAH ${ }^{1}$; MAHMOUD ELKADRAGY ${ }^{2}$; AHMED SHARSHER $^{3}$; \\ REDA RASHED ${ }^{4}$ and HAMED T. ELBAZ ${ }^{5}$ \\ ${ }^{1}$ Department of Veterinary Surgery, Anaesthesiology and Radiology, Faculty of Veterinary Medicine, Sohag University, \\ 82524 Sohag, Egypt. \\ ${ }^{2}$ Department of Egyptology, Faculty of Archaeology, Sohag University, 82524, Sohag, Egypt. \\ ${ }^{3}$ Department of Veterinary Surgery, Anaesthesiology and Radiology, Faculty, of Veterinary Medicine, University of Sadat \\ City, Egypt. \\ ${ }^{4}$ Department of Anatomy and Embryology, Faculty of Veterinary Medicine, University of Sadat City, Egypt. \\ ${ }^{5}$ Department of Theriogenology, Faculty of Veterinary Medicine, University of Sadat City, Egypt.
}

Received: 23 June 2019; Accepted: 30 July 2019

\begin{abstract}
The present study was aimed to through light on the status of veterinary surgery and gynecology in the ancient Egypt. Data come from the medical papyri of the ancient Egyptians, tomb scenes and other finds related to the subject. The reviewed and discussed sources include papyrus of Kahun, papyrus of Edwin Smith and papyrus of Ebres while tomb scenes include that of Kom Ombo temple. Kahun papyrus contains informations on veterinary gynecology and surgery. Edwin Smith papyrus illustrates many surgical cases in human such as injuries and traumas. The Ebers papyrus talks about different surgical conditions in human including abscesses, tumors and burns and referred also to surgical instruments. Surgical sutures were mentioned by the three papyri. It can inferred that awareness of Ancient Egyptians with different surgeries in human and animals, and the occurrence of the same surgical lesion in human and animal may suggest the same dealing.
\end{abstract}

Key words: Ancient, Egypt, Veterinary, Surgery, Gynecology, Papyrus

\section{INTRODUCTION}

The earliest veterinary document discovered is affined to Ancient Egyptians, it is the Papyrus of Kahun [ca., 1900 BC], which have texts dealing with animal diseases (von den, 2001). Generally, there is inadequate information in the Egyptian papyri on human or animal surgery although the oldest known metal surgical tools in the history were discovered in Egypt, particularly in the tomb of Qar. Such tools were made of bronze or copper (Hawass, 2003). Drawings of Ancient Egyptians and their papyri (like papyrus of Edwin Smith and Papyrus of Ebers) refer to different surgical conditions in human. These conditions include traumas, wounds, fractures, animal bites and joints dislocation and sprain (Sullivan 1996; Blomstedt 2014). Also, they illustrate serpent bite and scorpion sting in the Metternich Stela* (Scott, 2013). Ancient Egyptians performed also separation of trapped parts from rest of the body either for human or animals (Kirkup,

Corresponding author: Dr. Bahaaeldeen A. Abedellaah E-mail address: bahaa212121@yahoo.com

Present address: Department of Veterinary Surgery, Anaesthesiology and Radiology, Faculty of Veterinary Medicine, Sohag University, 82524 Sohag, Egypt.
2011). Fischer (1988) pointed to another Egyptian papyrus $(257 \mathrm{BC})$ refers to the presence of a professional horse doctor in Egypt at that time.

Relief pain prior to surgery was established by many ancient civilizations including the Egyptians, Greeks, Assyrians, Babylonians, Hindus and Chinese through some plants such as "the mandrake" which used by Babylonians more than 2000 years B.C (Raper, 1946) while the Greeks were used it mixed with wine for the same purpose whereas Romans apply the most early discovered drug, Opium, as pain killer and anesthetic in Middle Ages (Ellis, 1946).

The current study aims to through the light on the status of veterinary surgery and gynecology in the ancient Egypt.

\section{MATERIALS AND METHODS}

Data of the present study come from the medical papyri of the ancient Egyptians, tomb scenes and other finds related to the subject. The reviewed medical papyri include papyrus of Kahun, papyrus of Edwin Smith and papyrus of Ebres while tomb scenes include that of Kom Ombo temple. The study focused on the surgical cases which mentioned in 
such sources and, at the same time, had similar occurrence in both human and animals. The study referred to the recorded cases related to animal gynecology as well. On the light of the modern literatures, all of those sources were reviewed and discussed with the concentration on what's found referring to veterinary surgery and gynecology in the Pharaonic era and recoded by Ancient Egyptians.

\section{RESULTS}

Kahun papyrus is the oldest known medical text ever. The papyrus (fig. 1) is three sheet document one meter long and about thirty-three $\mathrm{cm}$ wide and consists of sections, one of these sections deals with veterinary sciences. Such section is written in hieroglyphic script unlike the rest of the papyrus which is written in Hieratic script. In the veterinary section, Kahun Papyrus points to veterinary gynecology and some diseases in cattle, dogs, birds and fish in addition to their treatments.

The kahun medical papyrus certificates the attendance of Ancient Egyptians with the animal ophthalmology. They handle treatment of eye problems in dog and bull. The intentional dog was suffered from a nest of worm in his eye, while the eye problems of the bull included the wind (cold ?) and trypanosomiasis. Remnants of the papyrus elucidate treatment of the wind (cold ?) eye problem as follow: \{If I see [a bull with] wind, he is. Let him be laid on his side, let him be sprinkled with cold water, let his eyes and his hoofs (?) and all his body be rubbed with gourds (?) or melons, let him be fumigated with gourds ......... wait herdsman .............. be soaked ............. that it draws in soaking .......... until it dissolves into water: let him be rubbed with gourds of cucumbers. Thou shalt gash (?) him upon his nose and his tail, thou shalt say as to it, "he that has a cut either dies with it or lives with it." If he does not recover and he is wrinkled (?) under thy fingers, and blinks (?) his eyes, thou shalt bandage his eyes with linen lighted with fire to stop the running'\}. With regard to eye influence due to trypanosomiasis, the papyrus mentions: (If I see a bull with [usham] in winter, and he is blinded (?) his two eyes are thick; gash thou as above. If I see a bull with ushau in winter from cold, since its arrival in (?) summer, his temples are wrinkled (?), his eyes running, his stomach groaning (?), he does not walk (?) ................... thou all its body with .......... as is done to one with a bruise (?)'.

Before the date of Kahun papyrus, some from tomb decorations (fig. 2) show the concern of Ancient Egyptians with veterinary obstetrics such as manual delivering of calves, removal of the placenta, maintaining offspring health, and the rectal and vaginal examinations of cattle. Such those veterinary obstetricians are known in Ancient Egypt as "overseer of cattle".
Edwin Smith medical papyrus (1534 BC) illustrates the dealing with many surgical conditions in human such as head injuries and trans-sphenoidal surgery. The papyrus gives anatomical description for suture of the skull, the meninges, the brain and the cerebrospinal fluid. The major part of the Edwin Smith papyrus is writes on surgical cases as injuries and traumas. Suture of the majority of the 48 surgical cases that described in the papyrus, prevention of infection using raw meat and promotion of curing using honey, all are written. For description suture of laceration, the papyrus mentions: 'If thou findest that wound open and its stitching loose thou shouldst draw together for him the gash with two strips of linen'. Also, the papyrus advises immobilization in case of bone fractures. Edwin Smith papyrus documented also traumas resulted from industrial accidents, warfare and animal bites. Such papyrus named the wound of soft tissues as "webenu or kefet", fractures as "heseb", joints dislocation as "wenekh" and sprains as "nerut". Moreover, the papyrus describes many forms of splints and bandages as tools for treatment and support of the different forms of fractures.

The Ebers medical papyrus (1550 BC) (fig. 3) talks about different surgical conditions in human including abscesses, tumors and burns, in addition to skin problems, dentistry, eye diseases, problems of the intestine and different gynecological matters. The papyrus discusses how to deal with tumors and refers to the cautery as a method of their treatment. Such papyrus refers also to piercing and pushing as a treatment of water of the abdomen and refers to the use of special knife in treatment of abscesses and tumors. Also surgical treatment of cyst and abscesses was described in the Ebres papyrus. Moreover, the papyrus mentions some surgical instruments which had been used by Ancient Egyptians at that time, these instruments include surgical knife or scalpel, saw, hooks, forceps pinchers and swelling remover.

Suturing of wounds was mentioned in Ancient Egyptians papyri under word ' $n d r y$ ' means "draw together" in four places; the first is in Kahun medical papyrus referring to bringing vaginal lips together to obscure passage while the second place is in Edwin Smith papyrus " 'thou shouldest palpate his wound, (and) draw together for him his gash with stitching', the third and fourth are in Ebres papyrus and denote stitching of the wound after lancing.

N.B: Our results were written on the light of the previous scientific researches in the field (Griffith, 1898; Breasted, 1930; Ellis, 1946; Schwabe, 1978; Van der Weijden and Rozendal, 1995; Saber, 2000; Amin, 2003; Steverding, 2008; Brorson, 2009; Kamp, 2012; Veiga, 2014). 


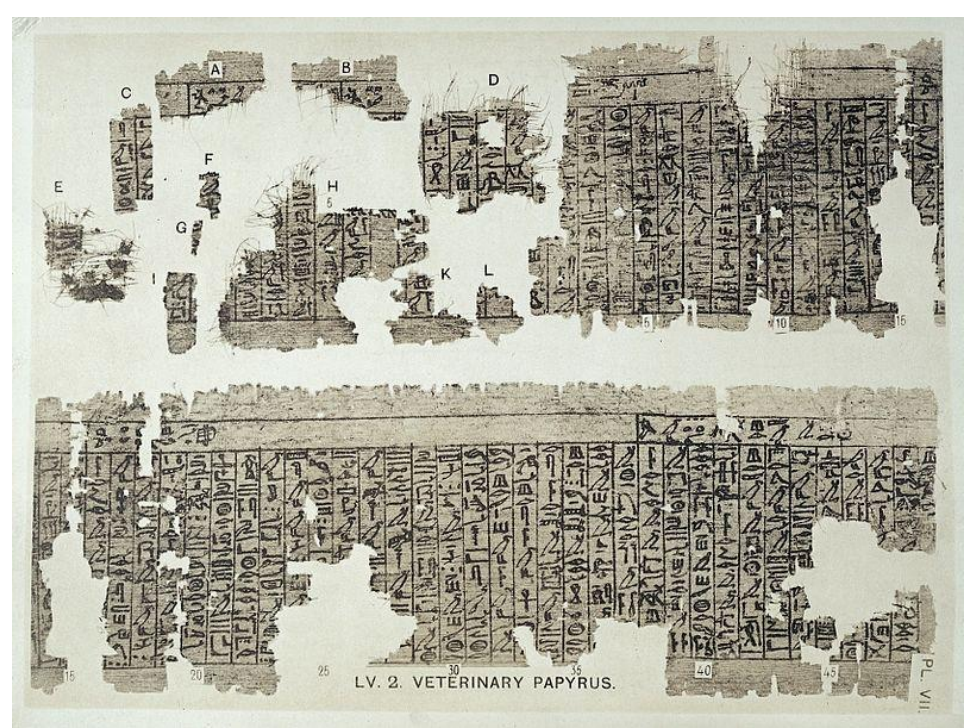

Fig. 1: The kahum medical papyrus. It was found at El-Lahun by Flinders Petrie in 1889, translated by F. Ll. Griffith in 1893, and published in The Petrie Papyri: Hieratic Papyri from Kahun and Gurob. It is the oldest known medical text in Egypt.

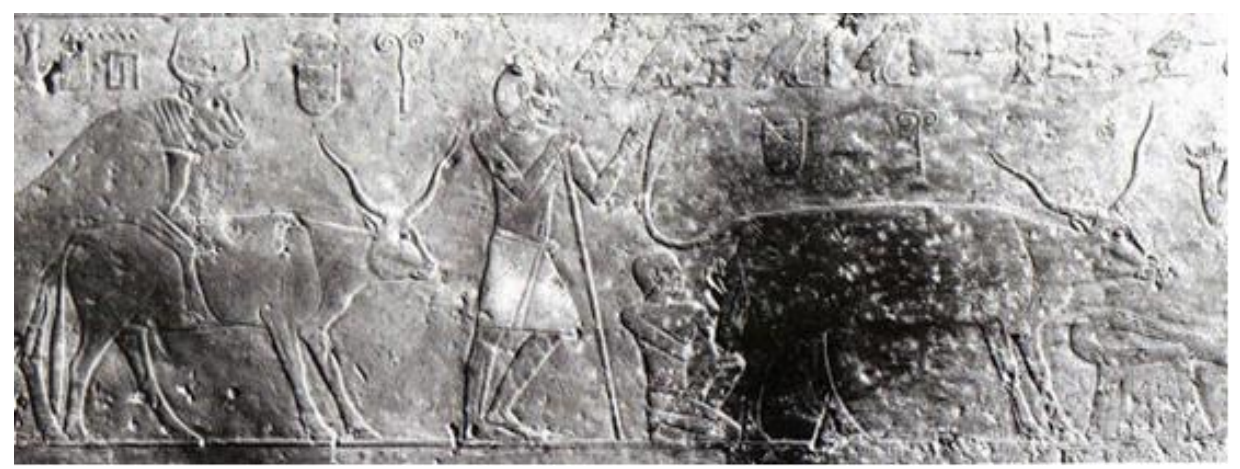

Fig. 2: Representation of natural insemination and gynecological examination in cattle Low relief, necropolis of Saqqara, Louvre Museum, Paris.

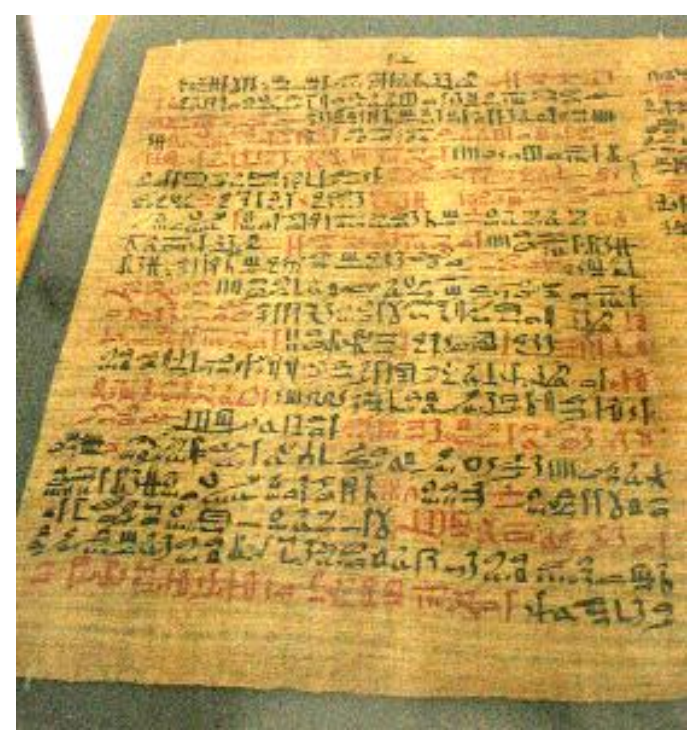

Fig. 3: The Ebers medical papyrus (1550 BC). It is a 110-page scroll, which is about 20 meters long. (Found in the library of the University of Leipzig, Germany). 


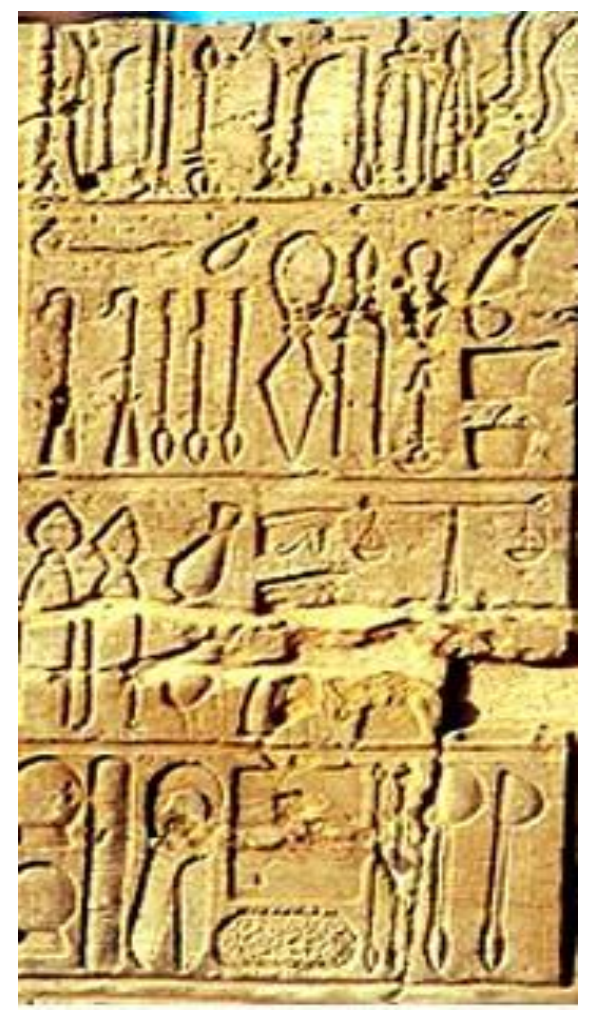

Fig. 4: Wall decorations of tools resemble surgical instruments in the temple of Kom Ombo.

\section{DISCUSSION}

One of the important facts throughout history is the belief that life could be sustained through the veterinary medicine and might be preserved through the human medicine. Such fact probably supports the early initiation of such branch of medicine (Guthrie, 1939). Unfortunately, activities of the predating societies are unknown for us because of their primitive life that made recording improbable whereas writing was regularly used in Egypt at ca., 3100 BC (Boltz, 1996). Medical sciences are one of these sciences which we know nothing about before writing discovery by Ancient Egyptians. However, and referring to some veterinary medicine information concerned with animal gynecology in one of its sections, the Egyptian papyrus Kahun dated to ca., $1900 \mathrm{BC}$ is actually the oldest known medical document ever.

Concerning veterinary surgery, the available data seems inadequate for researchers, but it is too early to confirm this opinion on the light of expansion of discovery all over Egypt. Especially when we know that Ancient Egyptians cared for animals; they domesticate felines and appreciated the cat as a sacred animal and used it in magic (Walter, 2007), furthermore, the fact that Egypt is one of these prehistoric civilizations that recorded different medical diseases and their treatment (Salem and
Eknoyan, 1999). Ancient Egyptians were pioneers in different fields like medicine and surgery (Fanous and Couldwell, 2012) and provided us with knowledge about diagnosing and treatment for many surgical condition in human ranged from head injury to trans-sphenoidal surgery as recorded in Ebers and Edwin Smith papyri (Loukas et al., 2011). The delightful thing for us is to know that Herodotus** writing pointed to the medical qualification in its widest sense, including the human and veterinary activities (Rawlison, 1956; Barguet and Roussel, 1964). Moreover, and according to Ancient Egyptian language, 'the doctors of ancient Egypt ' are called 'swnw' (Erman et al., 1971 III; Faulkner, 1972) such word likely related to two parts; swn, ' affliction' (Faulkner, 1972), and swnyt 'pain' (Erman et al., 1971 IV; Faulkner, 1972) or 'man of the pain' that used widely to refer to medical sciences including the veterinary field (Jonckherre, 1951; Barguet and Roussel, 1964).

Veterinary ophthalmology branch was practiced by Ancient Egyptians. They recorded the diagnosis and treatment of several eye lesions in dogs and bulls. Unluckily, damage of the Kahun papyrus deprived us to know the exact and complete protocol of treatment of these lesions. What is we can extract from remnants of the intended papyrus is the protection of the dog eye with linen bandage after steps of treatments which were missed in the 
papyrus. Nowadays eye bandage is recommended for protection, the same was prescribed by Ancient Egyptians. Also, cloudiness and thickening of the bull eye resulted from trypanosomiasis is mentioned accompanied by many general symptoms like stomach groaning and inability to walk (Steverding, 2008).

Ancient Egyptians knew also the sutures. They used hair, tendons, plant fibers and wool threads to stitch up the body after its evisceration for mummification purpose (Dawson, 1927, Snyder, 1977). Concerning wound sutures in the Egyptian papyri, Breasted, 1930 interpret what's mentioned in Edwin Smith Surgical papyrus about how the surgeons 'draw together" with 'idr'. The later author deduces that 'idr' could mean stitch (Erman et al., 1971 I; Faulkner, 1972). Furthermore, tools resemble surgical instruments (fig.4) were represented in the temple of Kom Ombo. These instruments are certainly used for mummification process but there is no evidence that they were used in surgery too (Sullivan, 1996).

From the study we can conclude awareness of Ancient Egyptians with different surgeries and obstetrical operations in human and animals, while occurrence of similar surgical lesion in human and animals is likely suggest possibility of similar treatment methods.

\section{REFERENCES}

Amin, O.M. (2003): Ancient Egyptian Medicine. Explore; 12: 7-15.

Barguet, A. and Roussel, D. (1964): Herodotus, $3^{\text {rd }}$ ed. Gallimard: Paris.

Blomstedt, P. (2014): Orthopedic surgery in ancient Egypt. Acta Orthopaedica, 85 (6): 670-676.

Boltz, W.G. (1996): "Early Chinese Writing", in The World's Writing Systems ed; Bright and Daniels: 191.

Breasted, J.H. (1930): The Edwin Smith Surgical Papyrus: Transliteration, Translation and Commentary; University of Chicago: Chicago, Illinois.

Brorson, S. (2009): Management of Fractures of the Humerus in Ancient Egypt, Greece, and Rome: An Historical Review. Clin Orthop Relat Res, 7: 1907-1914.

Dawson, W.R. (1927): Making a mummy. J Egypt Archaeol; 13: 40-9.

Ellis, E.S. (1946): Ancient Anodynes: Primitive Anaesthesia and Allied Conditions; WM. Heinemann Medical Books Ltd: London.

Erman, A. and Grapow, H. (1971): Wörterbuch der ägyptischen Sprache, new ed., Leipziog : 68 427.
Fanous, A.A. and Couldwell, W.T. (2012): Transnasal excerebration surgery in ancient Egypt. J. Neurosurg, 116 (4): 743-8.

Faulkner, R.O.A. (1972): Concise Dictionary of Middle Egyptian. Addenda and Corrigenda, Oxford, [Griffith Institute], 36: 217.

Fischer, K.D. (1988): Ancient Veterinary Medicine: A survey of Greek and Latin sources and some recent scholarship. Medizinhistorisches Journal, 23:191-209.

Griffith, F.L. (1898): Hieratic Papyri from Kahun and Gurob, London: 12-14.

Guthrie, E. (1939): History of Veterinary Medicine. The Veterinary Student. Iowa State University, 2(1): 6-10.

Hawass, Z. (2003): "The tomb of the physician Qar". Hidden Treasures of the Egyptian Museum: One Hundred Masterpieces from the Centennial Exhibition (Supreme Council of Antiquities ed.); American University in Cairo press, Cairo, Egypt: P. xx. ISBN 978977424778-1.

Jonckherre, F. (1951): A la recherche du chirurgien egyptien. Chronique Egypte, 51: 28-45.

Kamp, M.A. (2012): Traumatic brain injuries in the ancient Egypt: insights from the Edwin Smith Papyrus. J Neurol Surg A Cent Eur Neurosurg, 73(4): 230 -7.

Kirkup, J. (2011): A history of limb amputation. Eur J Orthop Surg Traumatol 21:459.

Loukas, M.1.; Hanna, M.; Alsaiegh, N.; Shoja, M.M. and Tubbs, R.S. (2011): Clinical anatomy as practiced by ancient Egyptians. Clin Anat, 24(4): 409-15.

Raper, H.R. (1946): Man Against Pain: Sci Illus; 1(7):57-61.

Rawlison, G. (1956): The History of Herodotus, $2^{\text {nd }}$ ed. Tudor Publishing Co. New York.

Saber, A. (2000): Ancient Egyptian Surgical Heritage. Journal of Investigative Surgery, 23: 327-334.

Salem, M.E. and Eknoyan, G. (1999): The kidney in ancient Egyptian medicine: where does it stand? Am J Ney, 19: 140-147.

Schwabe, C.W. (1978): Cattle, Priest and Progress in Medicine. University of Minnesota Press. Minneapolis. Volume 4; 214

Scott, N.E. (2013): "The Metternich Stela." The Metropolitan Museum of Art Bulletin.

Snyder, C.C. (1977): On the history of suture. Bull Hist Dent, 25:79-84.

Steverding, D. (2008): The history of African trypanosomiasis. Parasite vectors: $1-3$

Sullivan, $R$. (1996): The identity and work of the ancient Egyptian surgeon. J R Soc Med, 89: 467-473.

Walter, V.V. (2007): Contribution à l'étude de l'évolution historique du chat : ses relations avec l'homme de l'Antiquité à nos jours [en ligne]. Thèse de diplôme d'état : Docteur 
vétérinaire. Université Paul Sabatier. Toulouse.

Van der Weijden, G.C. and Rozendal, A. (1995): The history of bovine obstetrics. Argos, 13: 8186.
Veiga, P. (2014): Health and Medicine in Ancient Egypt: Magic and Science. Bar Archaeopress, Ludwig-Maximilians-University of Munich. Munich, Bavaria, Germany. 13.

Von den, D.A. (2001): Is there a veterinary papyrus of Kahun?. Hist Med Vet, 26 (3-4):105- 6.

* It is a magico-medical stele dates to the Thirtieth Dynasty of Egypt around 380-342 B.C. during the reign of Nectanebo II. It exists now in the Metropolitan Museum of Art, New York City.

** Herodotus; Ancient Greek Historian (484 - 425 BC), born in Halicarnassus in the Persian Empire (now Bodrum, Turkey), wrote the book "The Histories" and considers the first historical writer and often referred to as "The Father of History".

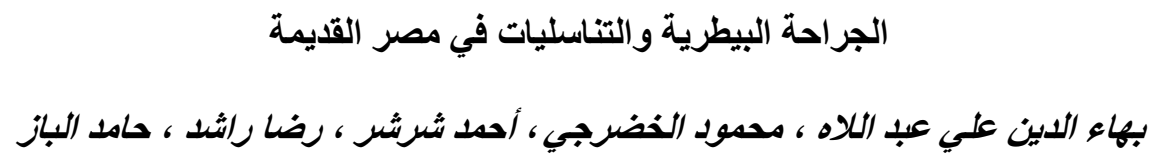

E-mail: bahaa212121@yahoo.com Assiut University web-site: www.aun.edu.eg

هدفت الدر اسة الحالية إلى تسليط الضوء على حال الجر احة البيطرية والتناسليات في مصر القديمـة اعتمـادا علي بيانات من البرديات

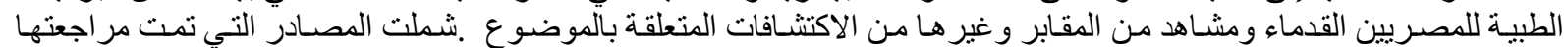

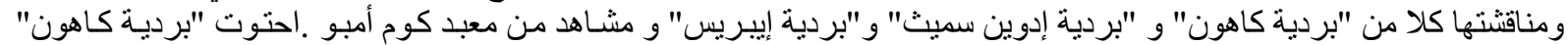

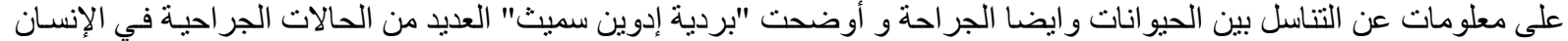

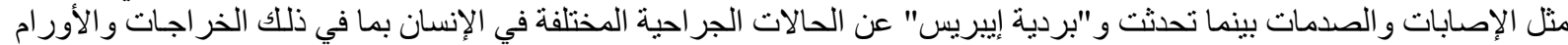

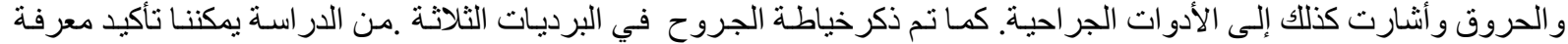

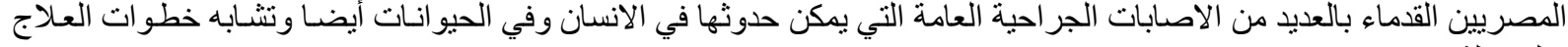

